\title{
Intergenerational Familial Ambidexterity in Polish Family Firms ${ }^{1}$
}

\author{
Piotr Preciuk², Ewa Wilczyńska
}

Submitted: 9.05.2020. Accepted: 9.10.2020

\section{Abstract}

Purpose: To explore how the predecessors and successors of Polish family businesses use and refine existing knowledge, identify knowledge deficiencies or absences, and create new knowledge during the Working Together stage.

Methodology/approach: The article builds on qualitative empirical material gathered in 2018 and 2019 with a problem-centered interview approach aiming to capture the complex and potentially diverging realities of both generations. Altogether, 48 preliminary interview questionnaires were completed and, subsequently, 46 interviews were conducted.

Findings: The study captured that the use of existing knowledge during the Working Together period is significantly supported by the fact that the old and young generation share several unarticulated beliefs, mental models, and behaviors. However, the identification of knowledge gaps and the creation of new knowledge are heavily hindered by the fear of confrontation and only declarative - instead of active - interest of the older generation in creating new knowledge.

Originality/value: The article bridges the gap between the literature on organizational ambidexterity and family business by empirically investigating the intergenerational dynamics of owners' families regarding knowledge creation. Moreover, we introduce the concept of intergenerational familial ambidexterity.

Keywords: family business, intergenerational cooperation, ambidexterity, change, continuity.

JEL: L20, M10, D22

\footnotetext{
1 The present study has been partially supported by Polish Ministry of Science and Education (Research Project no. MN2018.831.11). It reports on results gathered within a larger study into Intergenerational Knowledge Sharing in Family Businesses. In addition to it, the study was supported by the National Science Centre of Poland (Research Project no. 2018/29/N/HS4/02968: Organizational change and continuity in ambidextrous organizations).

2 Kozminski University, 59 Jagiellonska St., 03-301 Warsaw, Poland; https://orcid.org/0000-0003-4193-0979, e-mail: preciukp@gmail.com.

3 Kozminski University, 59 Jagiellonska St., 03-301 Warsaw, Poland; e-mail: ewaetna@kozminski.edu.pl.
} 


\section{Purpose and Motivation}

We are convinced that the presented results are significant for the development of scientific discussion in family businesses research as it focuses exclusively on intergenerational dynamics in owners' families through the lens of organizational ambidexterity (OA). We focus on the Working Together period, which is unique to family businesses, as its quality crucially impacts the quality of the next stage which is frequently denominated as the Passing the Baton stage, which refers to the succession process (Gersick, Davis, McCollom Hampton, and Lansberg, 1997). We follow the definition of Working Together that, "during this stage two or more generations are fully involved in the family business together" (Gersick et al., 1997).

The additional value of this article resides in the fact that the focus is placed on the intergenerational dynamic in owners' families who run family businesses in Poland. Because the majority of such firms were established after 1989 (Bednarz et al., 2017), approximately one-fourth of them are preparing for - or undergoing - their very first succession (Marjański and Sułkowski, 2019). Worldwide, family businesses are the dominant economic muscle of each nation (Poza and Daugherty, 2014; Klein, 2000). They account for $85 \%$ of all businesses and generate $70-90 \%$ of global GDP. Moreover, family businesses play a crucial role in generating jobs all over the world, creating $50-80 \%$ of job vacancies worldwide (Osnes, 2016). Peter Davis claims that each government that wants to improve its national economy should strive for improving the situation of family firms.

The transfer of a company to the next generation - especially when done for the first time - is a turning point that can lead to the firm's success or failure. As indicated by Stravrou and Swiercz (1998), on average only about 30\% of family-run companies worldwide survive up to the second generation, and barely $10 \%$ survive to the third generation. This high "fatality rate" can be attributed, among other things, to the mismanaged succession process (Le Breton-Miller, Miller, and Steier, 2004). As a result, research projects were set up to inquire on the determinants that impede or support the transition from older to younger generations.

Researchers in previous works started to inquire how the younger and older generation engage in knowledge creation and sharing since knowledge has been often "perceived as a kind of the company's 'anchor”' (Hadryś-Nowak, 2018), creating a competitive advantage and subsequently positively affecting intergenerational sustainability across generations (e.g. Chirico, 2008; Nordqvist and Chirico, 2010; Muskat and Zehrer, 2017; Woodfield, Shepherd, and Woods, 2017). Family business scholars claim that the 
phenomenon of intergenerational knowledge creation/sharing requires more attention as the existent studies are of anecdotal evidence (e.g. Woodfield and Husted, 2017; Ferrari, 2020). The prior research on knowledge creation/sharing in family businesses was primarily concerned with how the construction of the successor's knowledge and career development impacts his/her entrepreneurial orientation and, subsequently, the succession process (e.g., Cabrera-Suárez et al., 2018; Letonja and Duh, 2015). Another line of research focuses on the role of the founder/predecessor and how $\mathrm{s} / \mathrm{he}$ transfers knowledge to the next generation, therefore presenting knowledge creation/ sharing as a one-directional process: from the older generation as the source to the younger generation as the receiver (e.g. Letonja and Duh, 2016; Dou et al., 2020). Few researchers explicitly emphasize that the reciprocal active knowledge creation process is essential for successful business continuity across generations (e.g. Hatak and Rössl, 2015; Woodfield and Husted, 2017; Ferrari, 2020; Chirico and Salvato, 2016). Woodfield and Husted (2017) indicate the lack of research on how the younger generation's knowledge contributes to the family business. They show the critical differences between the predecessor and successor regarding their knowledge base. The former relies on tacit - thus experience-based - knowledge, while the latter relies on more explicit, formal (scientific) criteria, in some cases combined with the experience gained outside the family business. This article follows their path and presents both generations as equally valuable sources of knowledge that - when skillfully coordinated - contribute to the survival of the family business across generations.

As claimed in the previous works, the role of younger generations is to break an imposed path dependency (Lubinski, 2011), to renew and initiate the rebirth of their family business (Pacheco, 2019). However, breaking path-dependency is only possible if the older generation (OG) will be willing to accept and implement the fresh and new outlook of the younger generation (YG) for organizational ends (Chirico and Salvato, 2016).

Although the focal point of this research is placed on the Working Together stage, it treats knowledge ${ }^{4}$ creation/sharing as an activity that begins already at home, before the potential successor (YG) enters the business. Moreover, this article rests on the idea that intergenerational knowledge creation/sharing is a process of continuous mutual adjustment that happens between parent/predecessor and child/successor,

\footnotetext{
4 Knowledge in this article represents the interplay of tacit and explicit knowledge. The former exhibits a high level of tacitness, which means it is hidden in the conscious or unconscious sphere of the human mind in the form of "mental models, perceptions, insights, and assumptions" (Smith, 2001, p. 314). The latter is "described in formal language" (Smith, 2001, p. 315) and represents "formal education, or structured study .... Explicit knowledge is carefully codified, stored .... Once codified, explicit knowledge assets can be reused to solve many similar types of problems or connect people with valuable, reusable knowledge" (Smith, 2001, p.315).
} 
during which both parties evaluate each other and themselves (Matthews, Moore, and Fialko, 1999) to mutually align their roles (Handler, 1990). ${ }^{5}$

Interestingly, despite the declared awareness of how important the handover process is, most of the current owners of Polish companies - often company founders - report a lack of clearly defined succession plans (Kowalewska et al., 2009). Thus, we expected to observe a lot of learning, sense-making, ambiguity, and uncertainty on both sides: among the predecessors (OG) and successors (YG). As one of the interviewees put it:

"in most cases in Poland, the successors take over for the first time, but the predecessors pass on for the first time, and in fact, we all have to learn. ... The vast majority has never done it" (YG20).

\section{Research Methods, Paradigm, and Setting}

Our article is part of a larger study into intergenerational knowledge sharing in Polish family businesses during the Working Together stage, which strongly affects the succession process. The present study is of qualitative nature, which offers the most appropriate way to address the nuanced, complex, and potentially diverging realities of both generations. This study is positioned within an interpretive paradigm claiming that social reality is based on people's perceptions that must be explored to gain a better understanding of the researched phenomenon (Burrell and Morgan, 1979). Therefore, immersing ourselves in the world of the researched group was needed to discover essential patterns, themes, behaviors, and attitudes.

The present study represents a multi-level analysis, as recommended by Sharma (2004). It focuses on individual and interpersonal levels as units of analysis, namely on the younger and older generations working together in a family business. The inclusion of both generations in the study aims at overcoming the biases that might be generated when only the perspective of one generation is presented (Surdej and Wach, 2010). Moreover, as claimed by Yin (2009), the involvement of multiple participants in the research is preferable to triangulate data, and the insights coming from different actors may provide a richer picture of the phenomenon (Myers, 1997).

\footnotetext{
5 Mutual adjustment refers to everyday interactions, mechanisms, and practices that illustrate how the older and younger generations accommodate, negotiate with, and adapt to each other during the Working Together stage so as to bridge potential differences and opposing perspectives (adapted from Wapshott and Mallett, 2013).
} 
Due to the focus of the research, a purposeful sampling approach was applied. The companies had to meet the following criteria (Gersick et al., 1997; Creswell, 2013); younger generation already involved in day-to-day operations and initially identified as successors. Among the firms we studied, the predecessors and (future) successors had been working together anywhere between three and $20+$ years so it is safe to say that all of them were already in the working together phase. The research builds primarily semi-structured guide-oriented interviews with predecessors (OG) and their successors (YG), with additional 48 interview questionnaires that were collected at a preliminary stage. ${ }^{6}$ The purpose of the questionnaires was to gather basic information on successors' and predecessors' involvement, their relationship, and to what extent their perceptions converge on selected aspects related to intergenerational cooperation. The interviews happened between September 2018 and April 2019. They were recorded and transcribed by a professional transcription company. The average duration of an interview was 45 minutes. The firms ranged from micro to big companies and encompassed a range of industries. Most companies (20) were facing succession (hence the working together stage) for the first time, three companies for the second time, and only one company for the third time. The interviews were conducted separately with the younger and older generations, allowing them to express their views and opinions freely. The respondents' names were coded to ensure anonymity; however, the information about who belonged to the Older Generation (OG) and Younger Generation (YG) was preserved.

The qualitative methods represent a plethora of various practices and templates, rather than a "fixed battery of methods" (referring to Malkki, 2007, p. 181; Stewart, 2014, p. 77). Following this thought, the present research represents a mix of content and thematic approaches. As stated by Vaismoradi and Snelgrove (2019), content analysis "focuses on providing a simple, but in-depth report of commonalities and differences in the data," while thematic analysis expects "that the researcher will provide a rich and complex nuanced interpretation of the data as the theme.” Moreover, when analyzing the data, we applied a combination of inductive, thus bottom-up method - driven by raw data (Boyatzis, 1998) - and deductive, top-down method (Myers, 2013), driven by existing theory/prior research (Boyatzis, 1998).

The preliminary questionnaires have been filled in by the participants of the research before the interviews. This is in line with the problem-centred interview approach (Witzel and Reiter, 2012) 


\section{Theoretical Context}

\section{Organizational Ambidexterity}

Organizational ambidexterity (OA) was first proposed in 1976 by Robert Duncan who used the term "ambidextrous" for describing companies in search of long-term competitive advantage by combining seemingly disjoint strategies: exploration and exploitation. Since then, the research into OA grew significantly, and in 2013, Turner and colleagues offered a valuable synthesis of what the academic community understands under the term, which is going to be our theoretical framework in the present study: Ambidexterity is the ability to both use and refine existing knowledge (exploitation) while also creating new knowledge to overcome knowledge deficiencies or absences identified within the execution of the work (exploration) (Turner, Swart, and Maylor, 2013).

Although the concept of OA may be conducive to long-term competitive advantage and increased performance (Auh and Menguc, 2005; Gibson and Birkinshaw, 2004; Kauppila, 2010), practitioners and academics underline that it is difficult to achieve and maintain due to contradictory logics, which drive the use and refinement of existing knowledge (exploitation) and the creation of new knowledge (exploration). Originally, exploration was associated with innovation, significant change, and higher risk appetite, while exploitation links primarily to short-term efficiency, incremental change, process optimization, and broadly understood stability (Gibson and Birkinshaw, 2004; O'Reilly and Tushman, 2013). Because the constructive balancing of these (seemingly) opposing logics is an ongoing challenge, several researchers embarked on a quest to investigate if and how companies, teams, and individuals can accommodate them.

In our article, we refer specifically to the top-management-centric model of managing exploitation-exploration tensions, which claims that the "cognitive frames and processes allowing to effectively embrace, rather than avoid contradictions, occur either with the senior leader [owner/predecessor] or in the interactions of the entire top management team [predecessor/successor pair]" (Smith and Tushman, 2005).

Translating this thought into the context of family firms, the simultaneous involvement of current owners (OG) and their successors (YG) offers an opportunity to introduce and develop the "contradictory yet interrelated" elements that underpin OA. Actions and perspectives of the OG approximate the logic of exploitation (incremental change, stability, short-term efficiency), whereas the YG can be perceived as the force of exploration (significant change, innovation, risk). Thus, the way in which owners (OG) and successors (YG) work together can tell us if and how they use and refine existing 
knowledge, constructively identify knowledge deficiencies or absences, and finally, create new knowledge.

\section{The Working Together Stage}

As observed by Gersick et al. (1997), the period known as the Working Together stage has a strong imprint on the family and business systems. As close family members, usually parents and children, the OG and YG already know each other extensively. During this period, they "discover" each other in such terms as work preferences or business strategies, and their mental models may become more evident.

The Working Together stage happens when two or three generations (grandchildren) engage in running the family business. At this stage, the dynamics and interactions within the family and the business become even more interwoven. Therefore, managing the complex relations between the predecessor (older generation), the potential successor (younger generation), and other family members is the key challenge that the family faces. As claimed by Lansberg (1999), when working together and planning continuity across generations new forms of bonding might emerge, when the aspirations, wishes, expectations will be made explicit and diverging perspectives bridged.

Fostering intergenerational cooperation and managing conflicts are most critical at this stage. Open and constructive communication based on trust, mutual respect, sensitivity to each other's needs, and shared values nurtures cooperation between the generations (Sharma, 2004; Handler, 1989; Habbershon and Williams, 1999). In order to be constructive, communication between the generations should be based on open dialog, in which both the older and the younger generations are equally valued, although they sometimes represent different viewpoints. Habbershon and Astrachan (1997) indicate that "dialogue is a valuable tool by the means of which each individual can contribute to the creation of a larger, "collective pool of knowledge." When dialog is ensured, family members might reassess their old routines and beliefs and trade them for new ones.

The quality of the Working Together stage depends on the communication that builds on honesty, openness, and consistency. As argued by Lansberg (1999), the Working Together stage "might be the last opportunity the parents will have to instill in their children the skills, values, and attitudes necessary for family business continuity" (p. 153). However, the older generation "rather than only trying to teach ... should also make an effort to learn" (Korine, 2017, p. 69), if it wants to establish a collaborative environment based on constructive dialog that will drive the family business across generations. 
Moreover, as Gersick et al. (1997) indicate that establishing the 'linking mechanisms' between family and business structure permits the family unit to foster intergenerational collaboration and the smooth handling of a family business, even though power may be decentralized and diversified. Generational differences in opinions regarding strategy, management, vision, or values might be constructively resolved when communication is based on honesty, openness, and consistency in the family business system as a whole.

\section{Findings}

While analyzing collected data, we discovered the following patterns that can help answer our research question of how the predecessors (OG) and successors (YG) - working together - use and refine existing knowledge and competences, identify knowledge deficiencies or absences, and create new knowledge.

\section{Using and Refining Existing Knowledge and Competences}

We identified the following tendencies of the owner's families related to exploiting the knowledge already existing in their family firms.

First, as reported by the YG, the family business was an inseparable part of their childhood life. Through shared experience and close emotional and territorial proximity they learned and acquired the values from their parents. The YG unconsciously internalized and integrated the existing knowledge about their family business. The acquired knowledge remained almost completely non-articulated, tacit.

When it comes to the specifics [of the firm], I grew up in this company. I've been there from the very beginning. (YG1)

The factory was at the back of the house, so I was also playing with my brother. We played at the carpentry shop .... So, naturally, this knowledge was instilled in us .... I myself acquired a lot of knowledge through observation, walking. (YG14)

Second, the YG struggled to elicit from the OG the detailed operational, tactical, and strategic knowledge about how the firm is managed. This was partly because the OG assumed that their offspring naturally and tacitly absorbed all the necessary know- 
ledge. Nevertheless, the YG feared that they might not have enough knowledge and insight to ensure the continuity of the company after the OG would no longer be there.

Today, knowledge is there, because [Dad] is around, but if he won't be here, everything will dissolve and only that what we remember will remain ... we do not have it written down in any way. (YG4)

Third, YG had difficulty building a coherent picture of their role and responsibilities in the company, which resulted from mixed and incoherent messages from the OG about the expectations towards the YG.

What my Dad expects externally and what my Dad expects internally are two different things. (YG7)

Well, let me tell you, yes - theoretically I know [what the expectations are]. However, he says one thing and does another ... depending on the situation, these conversations are somewhat contradictory. (YG10)

When analyzing the data, we furthermore captured that the incoherent nature of expectations can be related to the fact that the OG struggles to present a clear vision to the YG. The following example provides an additional piece of information on why the expectations might not always reach the YG:

B: (researcher): Are you clearly communicating your expectations to the younger generation?

A: Maybe not always (OG20)

B: (researcher): Where does it come from?

A: I do not know. Maybe I'm too secretive sometimes. (OG20)

Even if the current generation (OG) knows the roles and responsibilities the future generation (YG) should play in the family business, the research shows that their expectations are often formulated in their heads, without being explicitly verbalized. As put by one of the interviewees (OG15), when asked if his offspring knows what he expects from him:

I think that ... subconsciously ... we are preparing the children for it [to take over the role]. But it's a very gentle process. 
Finally, the existing rules on how, where, and when to collaborate are introduced rather ad-hoc, informally, and with a relatively low level of discipline: with a loose and weak representation of processes, systems, structures. Spontaneous informal discussions focus more on operational (day-to-day tasks) and not strategic (long-term) planning:

Yes, you know, we meet here very often, to deal with matters as they arise ... there are no formal methods between ... us. This is ad hoc. (YG18)

I act more based on immediate need and a bit spontaneously. (OG17)

[Have you developed any common methods of cooperation?] No. For now, it is based on my rules. That's why I say that, you know, if the change in the company will come [i.e. succession], there will be an earthquake [a disruption]. (OG9)

[W]e have never had any so-called daily meetings, that we sit down at seven in the morning and say what needs to be done. (OG10)

\section{Identifying Knowledge Deficiencies and Absences}

We identified the following patterns related to identifying knowledge deficiencies or absences by the representatives of the OG and YG.

First, pinpointing knowledge gaps seems to not be the focal point of family members. There was even an apprehension that could be inferred from nonverbal cues during interviews. Two respondents expressed their worries already when sending back the initial questionnaires:

Attached I'm sending my answers. I gave the questionnaire to the older generation too. Please don't show him my answers because he might get offended :-) (YG16)

Attached is my Dad's survey. I think he tried to share it with you via Dropbox but I am not certain whether he was successful. I was kind of hoping not to see his answers, to remain ignorant, haha, but now that I have, I guess it might stimulate some discussions! (YG2)

However, apart from the uneasiness, there also was a mutual appreciation of each other's knowledge and skills. The analyzed material shows that the OG is perceived by the YG as a reliable and trusted source of information. 
I admire my father for something that is not tangible knowledge that can be sold but an amazing intuition for running a business. (YG10)

The older [generation] has more experience, the younger has less experience .... The older is influenced by their experience and the collected good and bad events they experienced in the past. (YG15)

Although we are the co-founders of the firm, but still, Dad is the person who has the most experience. (YG16)

While the OG appreciates the more modern knowledge and fresh outlook of the YG:

[The YG] learned the new working techniques that I learned not (OG9).

When asked about their own shortcomings, the OG mentioned that, unlike the YG, they are not fully up to date with the modern technology and business trends. Some of them expressed feelings of estrangement when it came to the practical application of current working and business methods.

I prepare a formal letter .... I have a secretary who writes it for me, or I send it to her, or I bring it and ask her to scan it for me .... I belong to the generation that uses a computer to write an e-mail, to communicate with the bank, and a few other things. (OG2)

Taking into account the last ten years, he has so much experience in this field, already more experience than me in terms of sales opportunities, models, and so on, and so on. (OG12)

On the other hand, when asked about the deficiencies of the YG's knowledge, the OG indicated almost exclusively the lack of experience and business intuition. They expressed concerns related to the YG's lack of knowledge validation on the "battlefield:"

I have experience. And you, gosh, unfortunately not. (OG20)

I put it all down to experience. Because you can be very well trained, prepared to perform a profession, but also a very important parameter is the experience gained in combat. (OG15) 
There is a lack of experience in some spheres, some kind of routine [of the YG]. (OG2)

The son makes [decisions] in the company, sometimes resulting from his inexperience and the fact that he is learning. (OG10)

Moving to the perceptions of YG's own knowledge deficiencies, they also indicate the lack of "business battlefield" experience. The OG is their reference point and role model. The knowledge stock of the OG - that builds on intuition (street smartness) or, as some call it, gut feeling - is valued by the members of the YG:

[S]ometimes I withdraw my opinion. Or I won't even speak up. Cause I rely on experience, position, wisdom and so on [of the OG]. (YG13)

[H]owever, this is an experience that we [the YG] do not have compared to them [the OG]; therefore, they sometimes prefer to patiently wait. (YG17)

This decision is supported by some reflection and it refers to experience, what happened in the past, what life or business experiences one has collected ... and this is what I would like to work on a little, to get this experience from him. (YG19)

[The OG] has an amazing intuition for doing business. And I'm afraid it's not transferable. I could inherit it in my genes, but it can't be learned. (YG10)

When the YG talked about the gaps and absences within the OG's knowledge, they indicated several main areas. Low level of formalized, documented, and transparent business procedures seemed to be one of the biggest challenges:

For me everything must be transparent, concrete. (YG9)

On the one hand, we know what we are doing, what we expect, and what we want to do; and on the other hand, we do not know [what we do] because there are no big plans, structures. (YG15)

[I]ntroducing structure to communication, certainly creates openness in information sharing. (YG1) 
This company was formed without any, I would call it, without specific rules. We are interested in producing and selling something ... This is what interests us, while everything else around us - i.e. in what conditions we do it, how does it happen, whether it is profitable or not - [all this] is another story .... [Moreover,] there is a problem with the flow of information in this company. (YG5)

Furthermore, the YG can also point to areas where OG's knowledge is deficient/outdated or requires validation:

I doubt that any company that wants to succeed nowadays would work like that ... without caring about the efficiency of the production process. (YG18)

Doing business nowadays relies more on current trends. In the past, it used to be that running a business was based only on know-how .... The market is developing so much that proposing the same to the next generation, I think it is my role not to do it. (YG2)

Next, the YG expressed concerns about the OG's difficulty in consulting and getting hold of external knowledge. The OG is much more reliant on their own inner circle of trusted workforce and well-tested methods that proved successful in the past:

I explain to him that certain things, certain investments must be made ... instead of asking a professional ... or an external company, we do it at our own expense that exceeds the costs of this [professional] company five times. (YG5)

What to fix, what to improve so that it gets better, so that we would have better profitability ... we are postponing this problem to hire an external advisor. None of the siblings, parents in the company or family want to deal with this topic. (YG9)

The YG's perception is also that the OG lacks a clear long-term vision for the family firm and does not specify the YG's role in it:

it is such (an immediate) temporary vision... we largely do not have [a solid vision]. (YG4)

Things that may be missing in our family are great strategy, this great long-term strategy ... we do not know whether Father will retire in three years or in 20 
years. Why should I think about succession ... as my Father can still work here for 20 years. (YG15)

It is difficult to say what my dad expects because he never had a vision that I must be the successor necessarily .... Dad is just happy that we are in the company (YG24)

Last but not the least, the YG worried about the OG's communication style, which they perceive as indirect, sometimes insufficient, and erratic:

[W]hen I ask, he will say it, but it does not come easily ... you have to ask carefully, clearly, because on his own he will rather be very paternalizing (YG16)

This [knowledge sharing] is more of a game, a detective game. (YG6)

Generally, he speaks little more than yes, yes ... yes .... However, between the lines ... I think he wants the level [of quality] to be kept. (YG21)

[M]y Dad must be reminded a few times and he has to be chased constantly. (YG24)

[V]ery often I do not have information, which I regret very much ... there is a problem with the flow of information .... There is a problem [that] some actions are taken without consultation with anyone else. (YG5)

[Y]ou must guess a lot of things, I must be very persistent, otherwise I won’t get what I want. (YG2)

Table 1 summarizes the main observations of one's own and the other's knowledge gaps described above. Table 1 clearly shows that there is a strong agreement when it comes to the knowledge gaps of the YG: both OG and YG indicate the lack of experience on the side of the YG as compared to the OG's experience, acquired through a long-lasting trial-and-error process. However, when we look at the knowledge gaps of the OG, the observations of the OG and the YG differ significantly. The OG talks mainly about their missing knowledge in technology and modern trends. The YG indicates areas related to the professionalization of communication and business operations, along with a transparent idea of how the company should develop and why a specific direction should be taken, without neglecting the YG's particular wishes and views. 
Table 1. Perception of own and others knowledge and competences gaps

\begin{tabular}{|c|c|c|}
\hline & $\begin{array}{c}\text { knowledge and/or competence gaps: } \\
\text { self-perception }\end{array}$ & $\begin{array}{c}\text { knowledge and competence gaps: } \\
\text { perception of others }\end{array}$ \\
\hline OG & $\begin{array}{l}\text { new trends in technology and business } \\
\text { approaches }\end{array}$ & $\begin{array}{l}\text { experience: lower level of proven usefulness } \\
\text { of knowledge } \\
\text { lack of validated knowledge in the 'battlefield' }\end{array}$ \\
\hline YG & experience / business intuition & $\begin{array}{l}\text { clearly defined long-term vision } \\
\text { too reliant on own modus operandi } \\
\text { ignoring the importance of formalization } \\
\text { and standardization } \\
\text { weak professionalization of communication } \\
\text { and collaboration } \\
\text { difficulty in seeking (external) advice }\end{array}$ \\
\hline
\end{tabular}

Source: own elaboration based on empirical material.

\section{Creating New Knowledge}

New knowledge creation is the third and final element of ambidexterity. It complements the two previous ones: using and refining existing knowledge and identifying knowledge gaps and absences. Importantly, during the Working Together stage that we studied, new knowledge creation means not so much what the OG or YG knows, says, and does, but how both generations combine what they know, say, and do. Our research indicates several patterns associated with new knowledge creation.

First, due to differences in the perception of knowledge gaps presented in the previous section, the process of new knowledge creation is far from straightforward. Instead, it is complex and challenging for both generations.

Most predecessors' perspectives tend to be path-dependent as they lean towards the status quo: "A man has habits ... a certain way of thinking, and not always having the modern approach of the young generations is acceptable (OG10)." Thus, the biggest challenge for the YG was observed in addressing the OG's path dependency, namely convincing the OG to accept different perspectives and approaches and adopt new ways of doing business. Overcoming path dependency was hindered by the fact that the YG's stock of knowledge represented a low level of proven record of past usefulness as compared to the OG, whose knowledge proved successful on many occasions. 
The way in which path dependency was approached by owners' families can be split into two broad categories: (1) the illusion of harmony combined with preserving the status quo and (2) agreeable disagreement linked to new knowledge creation.

The illusion of harmony could be observed in the area of professionalization of cooperation between YG and OG. Some of the OG representatives perceived defining and writing down rules and routines as a pointless exercise and a waste of time:

I am extremely lazy when it comes to writing down things that won't be later used. (OG17)

I'll be honest with you, I don't feel the need to create something like [a family constitution], I think it's somehow unnatural .... Well, we'll write something down but at the end what matters is what we actually do. (OG18)

On the other hand, some YG representatives would appreciate such a standardization but were discouraged because they expected that - even if defined - such rules and routines would not be adhered to by the OG:

Paper accepts everything. People can agree on paper, but at the end of the day, the owner can usually do anything. (YG20)

You know what, at the moment it's like this: as long as Father rules, the rules are his .... And whatever you write in this constitution, if he would make up his mind, then it would be the way he wants it. (YG10)

Path dependency was also clearly visible in the decision-making area. Although the YG already held key managerial positions in the family businesses, it was still mostly the OG who made the final decisions:

Anyway, I'm the CEO of this company, and I'm always right. (OG7)

Point A: Dad is right. Point B: If dad isn’t right, see point A. (YG16)

I'm the head of this company, so everything depends mostly on the decisions I make. (OG7)

Agreeable disagreement was observed in the minority of studied YG representatives and was usually initiated by the more straightforward and decisive standpoint of the YG. 
The perseverance and stubbornness of the YG was noticed by the OG - "They [the YG] are at times more aggressive, fierce ... sometimes the table is useful" (OG2) - implying that the table is sometimes needed since the exchange of views leads to exhausting and infuriating conflicts. Another respondent said that, "Well, it is very hard [to cooperate with the YG] because they have their own opinions and enough courage to question my various ideas (OG18).

In a few cases, family members - both older and younger - decided to combine their implicitly shared values, worldviews, and cognitive frameworks into explicit common rules of cooperation. They achieved it through the mutual engagement of both generations in decoding and negotiating their individual values. In the case of one company, family members working together decided to create a document that represented the values, which helped them to draw a vision to jointly run the family business. As claimed by one of them:

Our intention was to present our vision and the direction in which we are heading to the people who are working [with us[ now and who will work [with us] in the future ... we did not realize that when we verbalize it, it will be better and easier for us .... Maybe we used different words, but they appeared to be consistent with each other. (YG11)

To create this document, the family members met on a regular basis, and with the support of an external coaching company, they collectively developed their shared vision underpinned by four key values: trust, professionalism, commitment, innovativeness. Since each individual could understand these values differently, the family members jointly created a description of each value, along with a guideline on how family members should behave at the family and business level in order to live up to the established values.

Another family crafted a document that included family values, among other things, and called the document a family constitution. The document comprised the fundamental principles and guidelines that family members must follow when working in the family business. This constitution contains supplementary explicit directions for future generations on how to preserve the intergenerational character of the family business and how to maintain close relations with the local community. Apart from that, the constitution states that the dialog should remain at the center of each interaction in the family business. The aim of the family constitution was to clearly communicate in writing the expectations and responsibilities of family members actively involved in the family business. As stated by OG8, to bridge the existing intergenera- 
tional differences, one should talk with family members about their approach toward business and what they find to be essential:

[S]ince it was possible to talk about it and, at the same time, there are generational differences ... we faced them in order to get to know each other better in the family, in terms of approach toward the business. I was very eager to do it [to talk about it]. Since I started, I planted the seed, right. And they [the YG] are the ones who will cultivate this soil later on, right. This plant has already grown. (OG8)

We observed only in a few cases that new knowledge was created and implemented successfully. A minority of the predecessors acknowledged and even welcomed the need to introduce changes. Although it required from them mental and emotional effort, they showed more trust and had the opportunity to learn from their offspring(s):

[I]f I wouldn't trust the younger generations ... then our company wouldn't employ 200 people in 65 countries around the world ... the mistake is that many people don't trust the younger generations ... everyone thinks - "I will never die, I am eternal, I'm the smartest, I can't delegate tasks, but I'm cool because I invented all this" ... And this is not true at all. (OG17)

Although ... he is my son ... I also can learn something from him all the time. (OG21)

\section{Discussion}

In this section of our article, we present how the main constituents of organizational ambidexterity defined by Turner et al. (2013) - the use and refinement of existing knowledge, the identification of knowledge deficiencies or absences, the creation of new knowledge - apply to the phenomena we observed in the firms under consideration. We draw comparisons and conclusions to show how the dynamics of cooperation between the OG and YG during the working together stage may potentially give rise to intergenerational familial ambidexterity.

\section{Existing Knowledge: Tacit and Taken for Granted}

In our sample group, the use and refinement of existing knowledge meant making direct use of the knowledge, experience, and best practices created mainly by the OG 
before the working together period began. The acquisition and application of existing knowledge by the YG were significantly supported by the fact that they grew up and were socialized with the behaviors, values, and modes of operation of their parents (e.g. Bednarz et al., 2017; Cabrera-Suárez et al. 2018; Bika, Rosa and Karakas, 2019). Thus, most of the YG's existing knowledge was tacit and taken for granted. On the one hand, this constitutes an advantage as the OG and the YG share a vast body of knowledge, values, and beliefs that allow them to understand each other and cooperate more easily. On the other hand, such a set up generates multiple risks related to the downplaying of the importance of clear and explicit knowledge capturing and sharing. These risks appear in the prior research (Varamäki et al. 2015; Woodfiled and Husted, 2017), and our findings confirm these concerns. Although the YG expressed the challenges related to insufficient and sometimes missing definitions of the current ways of working and unclear expectations of the OG towards them, the OG seemed to discount and disregard such concerns. To the OG, the ways of working were self-explanatory, so they assumed that the YG would simply "get it" or would "muddle through it." As a result, the use of existing knowledge in the studied family firms prevailed. Unfortunately, sticking to the status quo usually leads to path dependency, which if not adjusted to the changing environment, may impede the development of innovations and the long-term survival of the company (Hirsch-Kreinsen, Hahn, and Jacobson, 2008). As noted by Cabrera-Suárez et al. (2018), "knowledge possessed by the predecessor can be easily outdated and not adequate for the current situation." However, sticking to solutions that proved successful in the past is easier, almost effortless, and thus tempting. The extant literature calls this a "success trap" or "competence trap," understood as a "focus on existing competences based on past success that prevents from adapting to the changing environment" (Wang, Serenate and Rafiq, 2015, p. 29). Our findings confirm that it is mainly the OG that falls for the success trap during the Working Together period.

\section{Knowledge Gaps Identification}

The field literature indicates that the ability of both generations to express and accept knowledge deficiencies is the necessary but insufficient precondition to embark on a journey to create genuinely new knowledge. In our data, we observe difficulty in the open expression and recognition of knowledge deficiencies. Particularly representatives of the YG seemed to worry that sharing their opinion may cause friction between them and their parents and break the harmonious familial environment. However, when asked in individual interviews, the YG was able to indicate several key areas in which the OG's knowledge and practices seemed insufficient or inadequate. Interestingly, these areas were significantly different from those that the OG perceived as their own knowledge gaps (see Table 1). This confirms that the YG strug- 
gled to effectively express their concerns and convince the OG that more attention should be paid to their suggestions and expectations. On the other hand, the OG remained convinced that their way of doing business is optimal and - apart from some minor adjustments - does not need changes.

Our data shows that the YG chose one of two paths: (1) the avoidance of potential confrontation by not sharing critical opinions or (2) attempts to have an open discussion that comes with a risk of family conflict.

The first approach represents an attempt to preserve harmony even though there are differences of opinion potentially worth addressing. However, such a harmony - or its illusion - breeds complacency and may lead to problems at family and business levels that will surface in the future (Jeżak, Popczyk, and Winnicka-Popczyk, 2004). As claimed by Lubinski (2011), the role of future generations is to unconsciously break the imposed path dependency. The successors must face the older generation who tries "to mold the successors into their own image" (Cabrera-Suárez et al., 2018, p. 185).

Some family members who become aware of the differing perspectives of the other generation may decide to address them openly: "I guess it might stimulate some discussions!" (YG2). As we signaled above, such discussions may lead to the weakening and initial disrupting of family harmony. However, in such a case, a family can make use of its unique assets, namely family intangibles - emotional attachment, shared values, and mutual respect - which are attributed to the "abundant history of interactions and interdependence existing in family ties" (referring to Pearson, Carr, and Shaw, 2008; Cunningham, Seaman, and McGuire, 2017; Marjański and Sułkowski, 2019). This is precisely the moment when the art of disagreeing agreeably becomes critically important.

Family members must learn how to disagree respectfully and constructively. It is not an easy or straightforward process. It is mostly messy, frustrating, and complex; progress and setbacks are likely to happen iteratively (Le Breton-Miller and Miller, 2005; Leach, 2017; Martin et al., 2019). Nevertheless, the effort seems to be worthwhile as both the literature (Leach, 2017) and our findings show that disagreements - if managed constructively - stimulate an open and honest exchange of views and form a microfoundation of organizational ambidexterity (Martin et al., 2019).

According to Leach (2017), there are three sources of problems (conflicts) encountered by family businesses, namely personal, business-related, and structural. The personal source appears when one of the family members is difficult to cope with since $s /$ he 
behaves irrationally. The business-related source of problems appears when financial performance decreases, and no one can tell if it is related to the poor performance of the family or the business. The structural source appears when one of the elements responsible for governing family-business interaction fails. Our data do not indicate that the businesses we studied faced personal or business-related problems. Thus, we agree with Leach (2017) that most problems reside in the structure. Therefore, following his line of thought, a great number of problems and conflicts in the family might be managed through the application of family governance structures and mechanisms (e.g. family meetings, a family constitution). These solutions might facilitate productive and proactive conflict management in the owner's family, even before the problems surface (Koładkiewicz, 2015).

Collected data indicate that not much open disagreement happened among the studied families. It is hardly surprising, keeping in mind the messiness and emotional toll associated with confrontations among family members. There were minor differences of opinions but open disagreements were rare. Interestingly, the few interviewees who admitted to having had more open, confronting discussions were usually - but not always - from owners' families that declared they jointly created new knowledge. This agrees with the view that constructive conflict happens when diverging perspectives "are accepted and appreciated, and where the debate leads to positive, creative outcomes" (Leach, 2017, p. 133).

\section{Creating New Knowledge}

For the purpose of this discussion, we define new knowledge as the product resulting from honest, thoughtful, and open cooperation between the younger and older generations. Reciprocal respect for each other's knowledge, experience, needs, expectations, emotions, beliefs, values, and perspectives is the necessary condition for new knowledge to be forged. Knowledge created in such a way has the possibility to result in workable solutions that acknowledge the past, but also make the company ready for a challenging future.

Examples of such new knowledge that we observed among the studied generations include the internationalization of family business and the introduction of family governance mechanisms such as family constitution and code of values. ${ }^{7}$ On a more operational level, these included formal patterns of communication (regular family meetings with set agenda and rules of behavior), guidelines on how family members

7 From the Polish kod wartości. 
should behave at the family and business level in order to live up to established values, and explicit directions for future generations on how to preserve the intergenerational character of the family business and how to maintain a close relationship with the local community.

As we presented in the previous section, the effort to initiate the creation of new, collective knowledge is not negligible. It calls for courage and decisiveness in expressing opposing or diverging views, but it can be done in a way that will not lead to destructive conflict. Thus, it is of the highest importance to provide specific mechanisms, structures, and platforms for constructive interaction, in which the conflicting interests of family members might be lessened and the feeling of belonging to the family and the family business can be strengthened (May and Bartels, 2017, p. 87). Providing shared space/s to educate and integrate family members and celebrate togetherness as a family is a necessity if the family business wants to leverage its potential. Creating collective knowledge while working together is all about providing a space where conversation can take place, "a space where disagreement does not mean putting the relationship on the line (96) ... better communication enables us to make better decisions (both individually and collectively) (120) ... and deal more constructively with the difference" (Marsh, 2018, p. 96, 120).

Apart from that, the OG should provide the YG time and space for feedback, intergenerational learning, discussing ideas, and friendship, which should begin even before the YG enters the business and continue as the relationship at work progresses (Cabrera-Suárez et al., 2001). The education should aim at gathering knowledge from the YG and the OG to create "group wisdom." Therefore, we should remember that education is relevant not only for the YG but for the OG as well. It frequently happens that the predecessors exhibit a low level of retentive capacity, thus they prefer to stick to the status quo. Hence, the OGs rely on their competencies, frequently rejecting new ideas, and potentially underestimating the YGs' competences.

Because the competences are not equally treated, the potential for intergenerational bridging remains unexploited. For many reasons, the YG's competences are not equally treated. The YG remains viewed as children and not as equal partners, as Korine claims (2017) "[e]ven before succession is formally on the table, the current generation of leaders has a lot to learn from its potential successors” (p. 69).

Succession is not a process, project, or work with an end date. The risk of falling into a path dependency/success trap persists. The routines must be regularly reevaluated and adjusted if necessary. Thus, the deep value of the whole process seems to be not 
the creation of family constitution or other formal documents and putting it on a shelf but on learning - both by the OG and the YG - how to continuously and constructively talk to each other, address differences, and disagree agreeably.

\section{Conclusions}

Our research shows that the Working Together stage in a family business carries the potential to instill the complex yet beneficial organizational ambidexterity logic into a family company.

\section{Intergenerational Familial Ambidexterity}

We define intergenerational familial ambidexterity as the ability to bridge diverging perspectives of two or more generations involved in running a family firm in order to advance change without getting stymied by operational routines and emotional attachment to the status quo. While using and refining existing knowledge ${ }^{8}$ (exploitation), both the older and the younger generation may encounter knowledge deficiencies or absences. The articulation and acknowledgment of these deficiencies may be a "stormy" process for the family members/business partners to go through. However, constructive disagreement is a valuable catalyst with which family members can contribute to the creation of a larger, "collective pool of knowledge." When consciously and jointly orchestrated, family intangibles such as shared values, emotional attachment, mutual trust, and respect might serve as facilitators of conflict management. Consequently, the overarching aim of ensuring the cohesiveness of a family and the economic stability of a company can be achieved by operating in the present while acknowledging the past so as to collectively shape the future. In this way, a family company can stand to benefit from intergenerational familial ambidexterity.

\section{Limitations and Future Research}

As with all studies that rely on qualitative interviews, some caution is needed when interpreting its findings. Even in the most careful setting, both interviewees and interviewers can unintentionally bias the results. The unwillingness or inability of interviewees to truly express their opinions would negatively affect the results of the study. Moreover, the fact that our research is of qualitative nature makes its results

8 'Refining' existing knowledge should be understood as the implementation of minor, incremental changes rather than bold, revolutionary shifts. It should not be mistaken for renewal, recasting, or recreation. 
impossible to be generalized onto a wider population. Our research setting mainly focuses on first- and second-generation family businesses. Longitudinal studies or studies of older family businesses - those currently run by a third, fourth, fifth, or an even later generation - could investigate how and if intergenerational familial ambidexterity works in the long term; how and if the synergistic relationship of the OG and the YG survives, develops, and continues or whether it succumbs to forces of path dependency. Furthermore, it would be interesting to investigate how the duality of family-business logic - very widely discussed in the literature - can interplay with the duality of OA in family firms. Finally, following the calls of Ahmad and Farhan (2019), future research could focus on hidden elements of knowledge sharing/creation, such as conflicts, commonalities, and differences between the older and younger generations and how they affect the creation of knowledge.

\section{References}

Auh, S., and Menguc, B. (2005). Balancing exploration and exploitation: The moderating role of competitive intensity. Journal of Business Research, 58(12), 1652-1661. https://doi.org/10.1016/j.jbusres.2004.11.007.

Bednarz, J., Bieliński, T., Nikodemska-Wołowik, A., and Otukoya, A. (2017). Sources of the competitive advantage of family enterprises: An international approach focusing on China, Nigeria and Poland. Entrepreneurial Business and Economics Review, 5(2), 123-142. https://doi.org/10.15678/EBER.2017.050207.

Boyatzis, R.E. (1998). Transforming Qualitative Information: Thematic Analysis and Code Development. Thousand Oaks, CA: Sage.

Burrell, G., and Morgan, G. (1979). Sociological Paradigms and Organisational Analysis. https://doi.org/10.4324/9781315609751-1.

Cabrera-Suárez, K., De Saá-Pérez, P., and García-Almeida, D. (2001). The Succession Process from a Resource - and Knowledge-Based View of the Family Firm. Family Business Review, 14(1), 37-46. https://doi.org/10.1111/j.1741-6248.2001.00037.x.

Cabrera-Suárez, M.K., García-Almeida, D. J., and De Saá-Pérez, P. (2018). A Dynamic Network Model of the Successor's Knowledge Construction From the Resource - and Knowledge-Based View of the Family Firm. Family Business Review, 31(2), 178-197. https:/doi.org/10.1177/0894486518776867.

Chirico, F. (2008). The Creation, Sharing and Transfer of Knowledge in Family Business. Journal of Small Business and Entrepreneurship, 21(4), 413-433. https://doi.org/10.1080/08276331.2008.10593433.

Chirico, F. and Nordqvist, M. (2010). Dynamic capabilities and trans-generational value creation in family firms. The role of organizational culture. International Small Business Journal, 28(5), 487-504. https://doi.org/10.1177/0266242610370402.

Chirico, F. and Salvato, C. (2016). Knowledge Internalization and Product Development in Family Firms: When Relational and Affective Factors Matter. Entrepreneurship: Theory and Practice, 40(1), 201-229. https://doi.org/10.1111/etap.12114.

Creswell, J.W. (2013). Qualitative Inquiry and Research Design: Choosing among Five Approaches (3rd ed.). Thousand Oaks, CA: Sage. 
Cunningham, J., Seaman, C., and McGuire, D. (2017). Perceptions of Knowledge Sharing Among Small Family Firm Leaders: A Structural Equation Model. Family Business Review, 30(2), 160-181. https://doi.org/10.1177/0894486516682667.

Dou, J., Su, E. Li, S. and Holt, D.T. (2020). Transgenerational entrepreneurship in entrepreneurial families: what is explicitly learned and what is successfully transferred?, Entrepreneurship and Regional Development. Routledge. https://doi.org/10.1080/08985626.2020.1727090.

Duncan, R. (1976). The ambidextrous organization: Designing dual structures for innovation. In: R.H. Killman, L.R. Pondy, and D. Sleven (eds.), The management of organization (pp. 167-188). New York: North Holland.

Ferrari, F. (2020). Organizational and Socio-Relational Factors Undermining Knowledge Sharing in Family SMEs. pp. 43-62. In: J.M. Palma-Ruiz, I. Barros, and L. Gnan (eds.), Handbook of Research on the Strategic Management of Family Businesses. https://doi.org/10.4018/978-1-7998-2269-1.

Gersick, K.E., Davis, J.A., McCollom Hampton, M., and Lansberg, I. (1997). Generation to Generation: Life Cycles of the Family Business. Boston, MA: Harvard Business School Press.

Gibson, C.C.B., and Birkinshaw, J. (2004). The antecedents, consequences, and mediating role of organizational ambidexterity. The Academy of Management Journal, 47(2), 209-226. https://doi.org/10.2307/20159573.

Habbershon, T.G., and Astrachan, J.H. (1997). Research note: Perceptions are reality: How family meetings lead to collective action. Family Business Review, 10(1), 37-52. https://doi.org/10.1111/j.1741-6248.1997.00037.x.

Habbershon, T.G., and Williams, M.L. (1999). A resource-based framework for assessing the strategic advantages of family firms. Family Business Review, 12(1), 1-25.

https://doi.org/10.1111/j.1741-6248.1999.00001.x.

Hadryś-Nowak, A. (2018). Family entrepreneurship orientation in family owned SMEs: A key resource for internationalization? Entrepreneurial Business and Economics Review, 6(2), 153-169. https://doi.org/10.15678/EBER.2018.060208.

Handler, W.C. (1989). Methodological Issues and Considerations in Studying Family Businesses. Family Business Review, 2(3), 257-276. https://doi.org/10.1111/j.1741-6248.1989.00257.x.

Handler, W. C. (1990). Succession in family firms. A mutual role adjustment between entrepreneur and next-generation family members. Entrepreneurship Theory and Practice, 15(1), 37-51. https://doi.org/10.1177/104225879001500105.

Hatak, I.R. and Roessl, D. (2015). Relational Competence-Based Knowledge Transfer Within Intrafamily Succession: An Experimental Study. Family Business Review, 28(1), 10-25. https://doi.org/10.1177/0894486513480386.

Hirsch-Kreinsen, H., Hahn, K., and Jacobson, D. (2008). The low-tech issue. In H. Hirsch-Kreinsen, and D. Jacobson (Eds.), Innovation in low-tech firms and industries (pp. 3-22). Cheltenham, England: Edward Elgar.

Jeżak, J., Popczyk, W., and Winnicka-Popczyk, A. (2004). Przedsiębiorstwo rodzinne funkcjonowanie i rozwój. Warszawa: Difin.

Kauppila, O. (2010). Creating ambidexterity by integrating and balancing structurally separate interorganizational partnerships. https://doi.org/10.1177/1476127010387409.

Klein, S.B. (2000). Family businesses in Germany: significance and structure. Family Business Review, 13(3), 157-181.

Koładkiewicz, I. (2015). System nadzoru w firmie rodzinnej. Doświadczenia polskie i światowe. Warszawa: Wydawnictwo Poltext. 
Korine, H. (2017). Succession for Change. Strategic transitions in family and founder-led businesses. Cham: Switzerland: Palgrave Macmillan.

Kowalewska, A., Szut, J., Małgorzata, B.L., Kwiatkowska, M., Sułkowski, Ł., Marjański, A., and Jaguszyński-Krynicki, T.J. (2009). Firmy rodzinne w polskiej gospodarce - szanse i wyzwania. Warszawa: PARP.

Lansberg, I. (1999). Succeeding generations : realizing the dream of families in business, https://books.google.pl/books?id=QE2HCgAAQBAJandhl=plandsource=gbs_book_other_versions

Le Breton-Miller, I., Miller, D., and Steier, L. (2004). Toward an integrative model of effective FOB succession. Entrepreneurship: Theory and Practice, 305-328.

Leach, P. (2017). Firmy rodzinne. Wszystko, co istotne. Warszawa: Wydawnictwo Studio EMKA.

Letonja, M. and Duh, M. (2015). Successors' Innovativeness as a Crucial Succession Challenge of Family Businesses in Transition Economies: The Case of Slovenia”. In: L.-P. Dana, and V. Ramadani (eds.), Family Businesses in Transition Economies. Springer, Heidelberg, pp. 57-174.

Letonja, M. and Duh, M. (2016). Knowledge transfer in family businesses and its effects on the innovativeness of the next family generation. Knowledge Management Research and Practice. Nature Publishing Group, 14(2), 213-224. https://doi.org/10.1057/kmrp.2015.25.

Lubinski, C. (2011). Path dependency and governance in German family firms. Business History Review, 85(4), 699-724. https://doi.org/10.1017/S0007680511001164.

Malkki, L.H. (2007). Tradition and improvisation in ethnographic field research. In: A. Cerwonka, and L.H. Malkki (eds.), Improvising theory: Process and Temporality in Ethnographic Fieldwork (pp. 162-187). Chicago IL: University of Chicago Press.

Marjański, A. and Sułkowski, Ł. (2019). The evolution of family entrepreneurship in Poland: Main findings based on surveys and interviews from 2009-2018. Entrepreneurial Business and Economics Review, 7(1), 95-116. https://doi.org/10.15678/EBER.2019.070106.

Marsh, I. A. (2018). If it so good to talk, why is it so hard. Rediscovering the power of conversation. UK: Matador.

Martin, A., Keller, A., and Fortwengel, J. (2019). Introducing conflict as the microfoundation of organizational ambidexterity. Strategic Organization, 17(1), 38-61. https://doi.org/10.1177/1476127017740262

Matthews, C.H., Moore, T.W., and Fialko, A.S. (1999). Succession in the family firm: A cognitive categorization perspective. Family Business Review, 12(2), 159-169.

https://doi.org/10.1111/j.1741-6248.1999.00159.x.

May, P., and Bartels, P. (2017). Governance im Familienunternehmen: Das Handbuch für die erfolgreiche Führung von Familienunternehmen und Unternehmerfamilien (1st ed.). Köln: Bundesanzeiger Verlag.

Miller, D., and Le Breton-Miller, I. (2005). Managing for the long run: Lessons in competitive advantage from great family businesses. Boston, MA: Harvard Business School Press.

Muskat, B. and Zehrer, A. (2017). A power perspective on knowledge transfer in internal succession of small family businesses. Journal of Small Business and Entrepreneurship. Taylor and Francis, 29(5), 333-350. https://doi.org/10.1080/08276331.2017.1345208.

Myers, M. D. (1997). Interpretive research in IS. In: J. Mingers and F. Stowell (eds.), Information systems: An emerging discipline (pp. 239-266). Maidenhead: McGraw-Hill.

Myers M.D. (2013). Qualitative Research in Business and Management. Thousand Oaks: Sage.

O’Reilly, C., and Tushman, M.L. (2013). Organizational Ambidexterity : Past, Present and Future. Academy of Management Perspectives, 27(4), 324-338. https://doi.org/10.5465/amp.2013.0025.

Osnes, G. (2016). Family Capitalism: Best practices in ownership and leadership. New York: Routledge. 
Pacheco, L. (2019). Performance vs. Family ownership and management: The case of portuguese wine firms. Entrepreneurial Business and Economics Review, 7(3), 7-24. https://doi.org/10.15678/EBER.2019.070301.

Pearson, A.W., Carr, J.C., and Shaw, J.C. (2008). Toward a theory of familiness: A social capital perspective. Entrepreneurship: Theory and Practice, 32(6 SPEC. ISS.), 949-969. https://doi.org/10.1111/j.1540-6520.2008.00265.x.

Poza, E., and Daugherty, M. (2014). Family Business (4th ed.). Mason, OH: South-Western/Cengage Learning.

Sharma, P. (2004). An Overview of the Field of Family Business Studies: Current Status and Directions for the Future. Family Business Review, 17(1), 1-36. https://doi.org/10.1111/j.1741-6248.2004.00001.x.

Smith, W.K., and Tushman, M.L. (2005). Managing Strategic Contradictions: A Top Management Model for Managing Innovation Streams. Organization Science, 16(5), 522-536. https://doi.org/10.1287/orsc.1050.0134.

Stewart, A. (2014). The anthropology of family business: An imagined ideal. In: L. Melin, M. Nordqvist, and P. Sharma (eds.), SAGE handbook of family business (pp. 66-82). Newbury Park, CA: Sage.

Stravrou, E., and Swiercz, P. (1998). Securing the future of the family enterprise: A model of offspring intentions to join the business. Entrepreneurship Theory and Practice, 23(2), 19-39.

Surdej. A., and Wach, K. (2010). Przedsiębiorstwa rodzinne wobec wyzwań sukcesji. Warszawa: Difin.

Turner, N., Swart, J., and Maylor, H. (2013). Mechanisms for managing ambidexterity: A review and research agenda. International Journal of Management Reviews, 15(3), 317-332. https://doi.org/10.1111/j.1468-2370.2012.00343.x.

Vaismoradi, M., and Snelgrove, S. (2019). Theme in qualitative content analysis and thematic analysis. Forum Qualitative Sozialforschung, 20(3). https://doi.org/10.17169/fqs-20.3.3376.

Wang, C. L., Senaratne, C. and Rafiq, M. (2015). Success traps, dynamic capabilities and firm performance. British Journal of Management, 26(1), 26-44. https://doi.org/10.1111/1467-8551.12066.

Wapshott, R. and Mallett, O. (2013). The unspoken side of mutual adjustment: Understanding intersubjective negotiation in small professional service firms. International Small Business Journal, 31(8), 978-996. https://doi.org/10.1177/0266242612450728.

Witzel, A. and Reiter, H. (2012). The Problem-centred Interview. Principles and Practice. Thousand Oaks, California: Sage Publications.

Woodfield, P. and Husted, K. (2017). Intergenerational knowledge sharing in family firms: Case-based evidence from the New Zealand wine industry. Journal of Family Business Strategy, 8(1), 57-69. https://doi.org/10.1016/j.jfbs.2017.01.001.

Woodfield, P.J., Shepherd, D. and Woods, C. (2017). How can family winegrowing businesses be sustained across generations? International Journal of Wine Business Research, 29(2), 122-139. https://doi.org/10.1108/IJWBR-12-2015-0052.

Yin, R.K. (2009). Case Study Research: Design and Methods. In: L. Bickman and D.J. Rog (eds.), Essential guide to qualitative methods in organizational research.

https://doi.org/10.1097/FCH.0b013e31822dda9e. 